\title{
At Large in the Empire of Things: The Museum of Sundry Objects
}

\author{
John Bodinger de Uriarte
}

\section{Abstract}

The Museum of Sundry Objects, located in Sólgarður, about 25 kilometers north of Akureyri, offers a site to think carefully about a number of key elements of museum practice, including the logic of collection, the practice of object 'array,' and the role of the museum 'heroic' object. Where the heroic object directs one to move from the individual to the imagined array, the array opens a different set of possibilities for recognizing the singularity of objects. In addition, a close examination of the Sundry suggests that 'the museum' may simply be one stage of many in the ongoing life of the object, an extended liminal phase that offers a number of opportunities for the re-enlivening of the objects, a different set of steps on the path of the in between.

Key words: Array, Heroic Object, Slow Events, Liminality, Inbetweenness, Collections

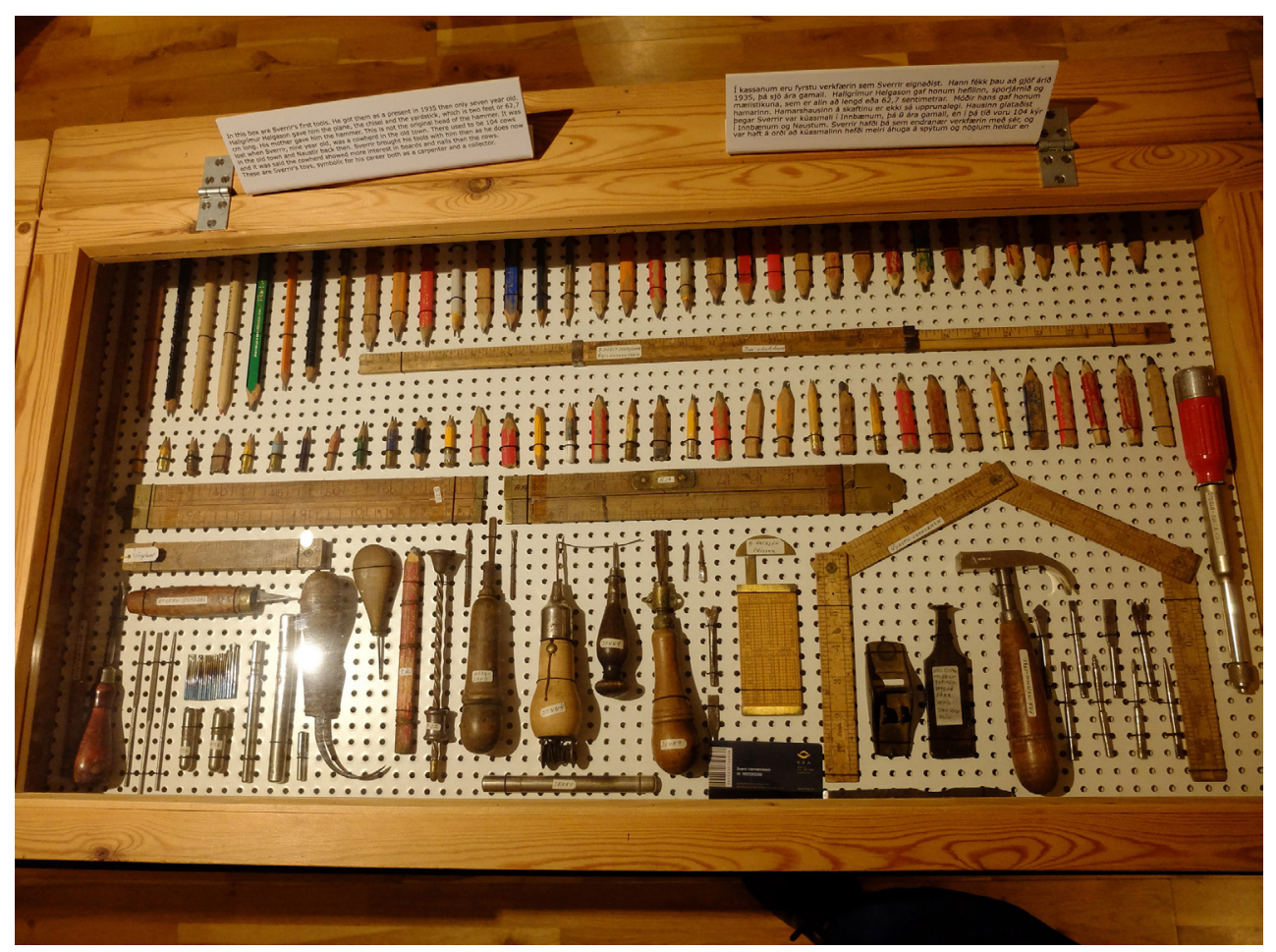

Figure 1 
In Vladimir Nabokov's 1972 novel Transparent Things, the protagonist(Hugh Person) discovers a pencil stub in a desk drawer in his hotel room in Switzerland.

It was not a hexagonal beauty of Virginia juniper or African cedar, with the maker's name imprinted in silver foil, but a very plain, round, technically faceless old pencil of cheap pine, dyed a dingy lilac. It had been mislaid ten years ago by a carpenter who had not finished examining, let alone fixing, the old desk, having gone away for a tool that he never found. Now comes the act of attention (Nabokov 1972: 6).

The attention that Person brings to the object traces its histories, along the paths of the discovery of graphite, the harvesting of wood, the manufacture of pencils. The reader is tugged in different possible directions and distractions - 'side trips of inspection' - then redirected to the main focus, the 'transparent thing' that is the pencil in question. Transparency here is a recognition of the object as something to see through, a thing that both organizes attention and offers a multitude of different possible readings or narratives. Transparency, in Nabokov's terms, also recognizes the object as somewhat immaterial and elusive - there is no one story embedded here, waiting to be uncovered, but a range of interpretations, intersections, and entanglements. Having traced the pencil in question back through its use and manufacture, Nabokov takes us to one possible point of the pencil's origin: 'We recognize its presence in the log as we recognized the log in the tree and the tree in the forest and the forest in the world that Jack built' (Nabokov 1972: 7-8).

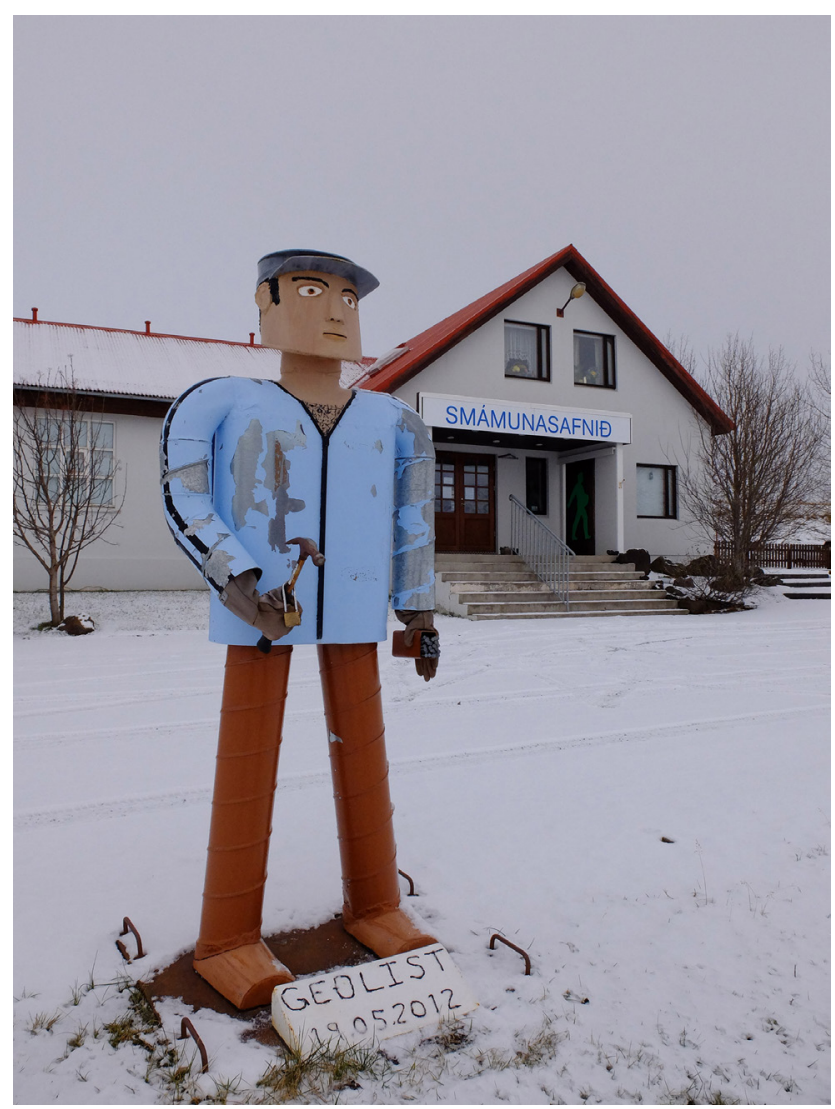

Figure 2. Exterior of the museum
I quote this passage at some length because it offers a recognition - or makes acts of cognition and speculation plain - in the face of objects. The sleight of hand buried in the story, perhaps, is the role of the narrator himself, creating the opportunities for pencil discoveries and wandering carpenters as unquestioned elements of the origin narrative of the interaction itself.

The Museum of Sundry Objects (Smámunasafnið) offers a wide array of interactions like the above, mundane objects pulled from the flow of time and space and arranged as objects of attention, objects that can arrest the visitor in their passage through the galleries, to stop them dead with recognition or nostalgia, speculation or curiosity.

Located in Sólgarður, Eyjafjarðarsveit, about 25 kilometres north of Akureyri, Iceland, the museum is housed in a repurposed municipal building that also served as a schoolhouse in its past. Featuring the life collection of Sverrir Hermannsson, the Museum of Sundry Objects 
offers an exhibitionary space dense with the display of 'miscellaneous things'. Born on 30 March 1928, Sverrir was a master house carpenter who specialized in the restoration of old houses and other structures primarily from the nineteenth century. '[His] workmanship can be seen in many of the oldest historical buildings in Akureyri, and he was also involved in the maintenance and rebuilding of several churches in Eyjafjörour: at the church farmsites Grund, Grenevík, Möðruvellir and other locations' (The Museum of Sundry Objects and Práinsdóttir 2017).

His work led him to a variety of objects - salvaged elements from houses and other buildings, objects discovered in crawl and storage spaces, nails and fixtures, things recovered from dumpsters and other places. As the museum's brochure states: 'Where others saw trash, Sverrir spotted treasures' (The Museum of Sundry Objects and Práinsdóttir 2017). $\mathrm{He}$ was an insatiable collector, adding over a thousand objects to his collection each year, sometimes absorbing other collections into his own. He arranged his collected objects carefully in specially-built cabinets and on custom-built display boards of various sizes.

A citizen of the original 'old town' of Akureyri in the Eyjafjörður district, Sverrir kept and organized the sundry items of his collection in Akureyri, until he gave it in its entirety to the district of Eyjafjarðarsveit in the spring of 2003, on condition that it be displayed in suitably spacious premises. The Museum is in Sólgarður, a district where Sverrir renovated a number of churches as a young man. He passed away on 12 July 2008. It is beyond the scope of this article to give Sverrir's story - either in terms of his biography or the full details of his collecting processes - the full attention it deserves. This article focuses on how the Museum of Sundry Objects works as a particular articulation of museum practices and immersive environments. The uniqueness of Sverrir's collecting practice, and the organization of the object displays, are what call the museum into place. My hope here is to introduce the museum and to focus on the singularity of its display practices and its visitor environments, so as to offer a series of critical reflections.

In pursuing the Museum of Sundry Objects, I draw from a number of different theoretical sources and historical moments. Cabinets of curiosity - widely recognized as the ancestors of modern museums - sought to wrestle the scope of the world into view through an encyclopedic collection of single, unique, 'heroic' objects. The breadth of the cabinet's displayed collection, and its variety, was an instrument of establishing order - both for the collected objects and the

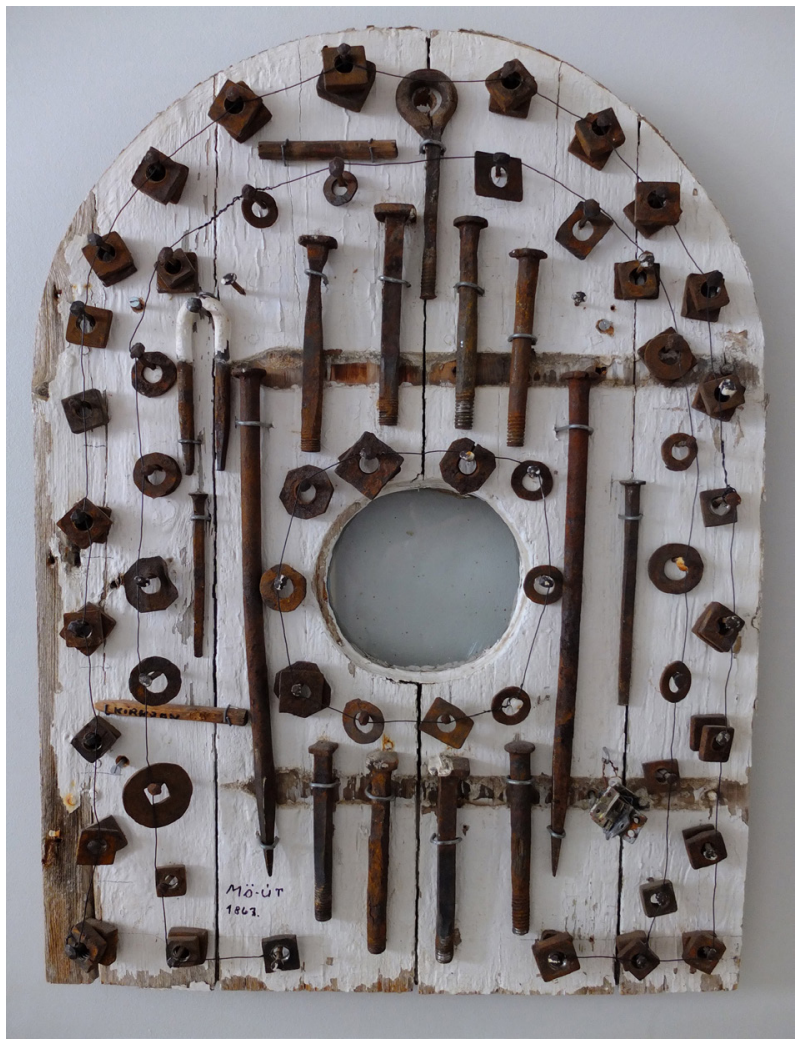

Figure 3. image from the collection world they reflected. As Susan Crane asserts: 
While elaborately decorated, portable Schränke, or cabinets, might house a special collection of valuables, the curiosity cabinet was a larger, immobile entity characterized by an interest in displaying a wide variety of natural and man-made objects in one place - the plentitude of the world represented in the microcosm of a single room or space (Crane 2000: 67).

While the Sundry may find an origin point in such cabinets, it works differently, through arrays of similar objects rather than singular 'heroes'. Its claim to the singularity of objects, however, is little different - the strategy of displaying multiple 'like' objects calls attention to the unique attributes of each. What the displays do, in part, is re-tune the visitor perspective, to seek difference in the similar. The majority of the objects in the Sundry show the marks of their own singular passage through time and use, 'worn with the hand's obligations, as by acids, steeped in sweat and in smoke' (Neruda 1974: xxi). The lived history of the objects reveals their singularity through their own constellations of wear.

In this article, I draw from Arjun Appadurai's seminal work on the social life of things (1968), paying close attention to things as objects of circulation and value. I also consider how value comes to things in 'arrest' - their trajectories halted or delayed by their placement in museums and exhibitionary spaces. My close attention to things also depends on Sherry Turkle's consideration of the things of everyday life as 'evocative objects [that] bring philosophy down to earth' (Turkle 2011: 8). Recognizing that things do not live in isolation, but are elements of entangled networks, I also consider Anna Tsing's use of Charles Darwin's 'tangled bank' (2017) to recognize the interdependencies of display objects, vernacular objects, and vernacular objects as display objects - none of these lives in isolation. Finally, borrowing from Barbara Kirshenblatt-Gimblett (2006), I use Stanley Eveling's concept of objects as 'slow events' to consider the extended activity of the objects on display in the Sundry, and to reflect on their long moment of attention in the museum. Cabinets of curiosity are sites for

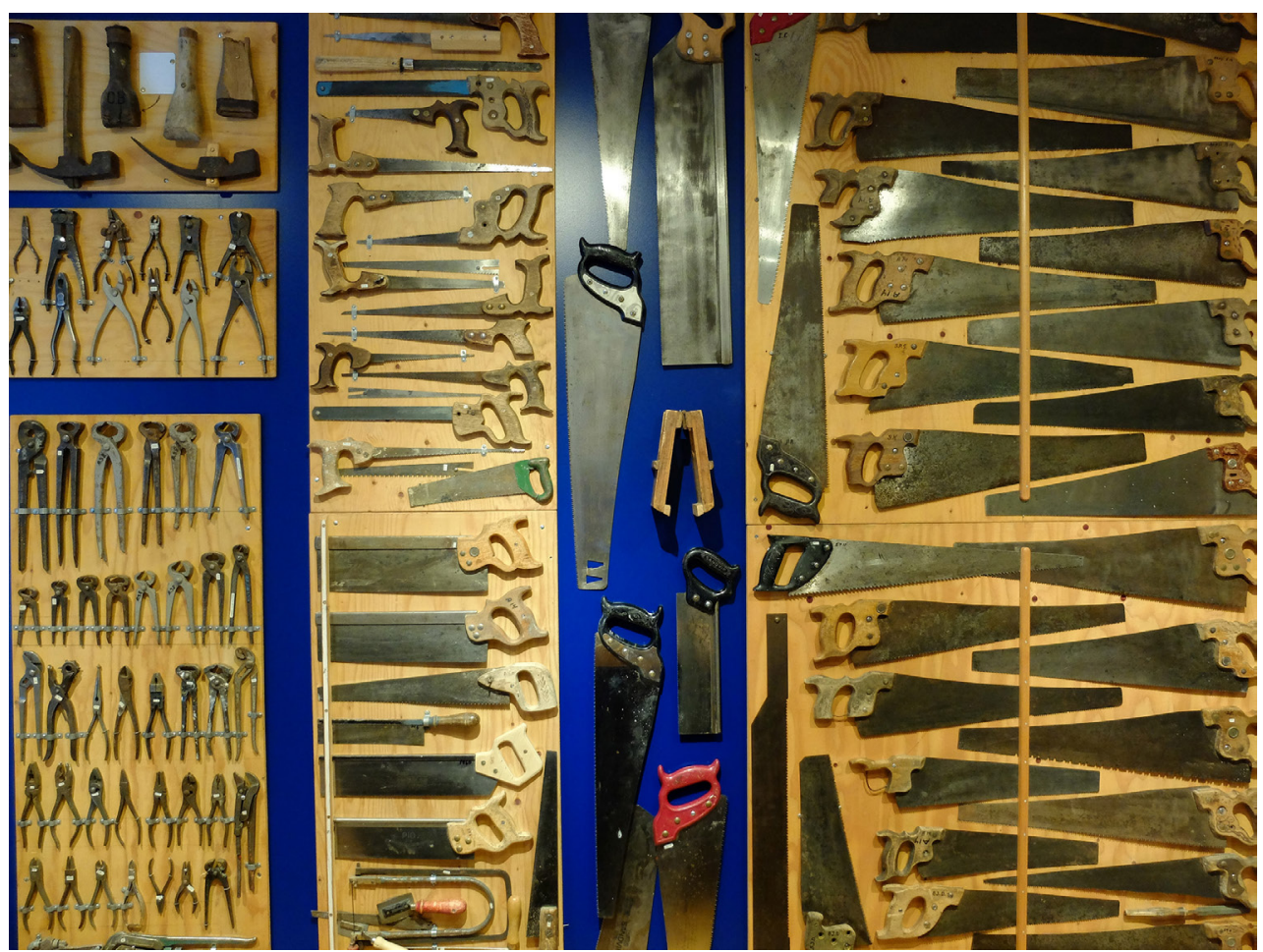

Figure 4 
singularities - the seashell, the tribal mask, the Roman artefact, the skeleton - each is given particular coherence through their gathering, establishing a network of meaning between distinctly individual objects. The Museum of Sundry Objects pushes back against this as, in many senses, the arrays of objects are given shared coherence through their similarity, through the histories of their use, through their arrested lives, and through their connections with one another.

The exhibition spaces in the Museum are thick with object density. While pathways through the galleries are clear and uncluttered, the walls feature panels offering arrays of handsaws, for example, or collected keys or lock-plates. Each object bears a set of handwritten initials indicating its origin - those that Sverrir collected, those that were donated, those that came from construction-site dumpsters or the Salvation Army. In some ways, this kind of display design hearkens to the sort of object-grouping used by the Pitt-Rivers Museum, for example; a typological system where similar objects are decontextualized or removed from their fellows to be recontextualized as a grouping and given new coherence through their assembly. One is more likely to find a handsaw, an auger, a hammer, and a screwdriver together as part of a set of carpenter's tools, for example, than to find a set of nothing but handsaws.

The exhibition space also indicates some of Sverrir's process in organizing and collecting. While most of the displays are tightly organized, with each element affixed to a board or ordered inside a case, there are two sets of open shelves that serve as gallery separators. On this shelving is a wealth of what appear to be disorganized objects, in somewhat stark contrast to the rest of the exhibition space. Here are the not-yet-assemblies from Sverrir's workshop, collections of things not yet wrestled into the same kind of order as the rest. It is easy to read the shelves' contents as illustrating an extended moment in the Museum's process, a place where things have eddied up against one another in soft collision, waiting for an articulation yet to happen. But the shelves also allow us to think about different systems of order and entanglement. They illustrate that the order of the other gallery elements indicates or establishes relationships that are just one of many (the objects could be ordered by owner, by productive clusters, by time period, by sites of discovery... the order of the objects both

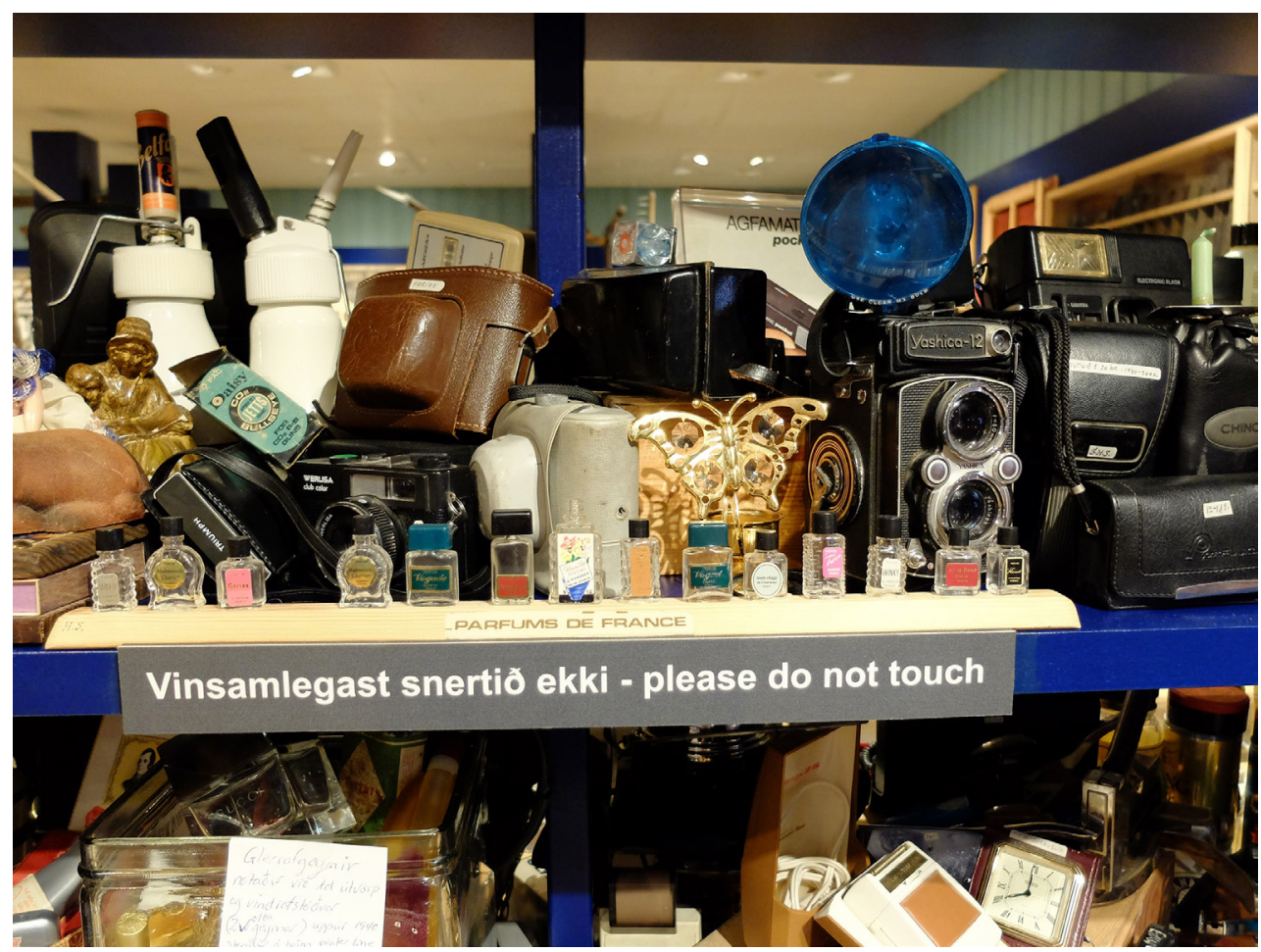

Figure 5. 
makes clear their relationships and creates those relationships as reflective of particular sets of imagined organizational logics). As Walter Benjamin suggests: 'Every passion borders on chaos, that of the collector on the chaos of memory' (Benjamin 1968: 60). In a recent work, Philipp Blom follows this to assert 'Order... is nothing but "a state of suspense over the abyss"' (Blom 2003: 207). The shelves and the ordered gallery exhibits give us different glimpses of this state of suspension.

But we need to be careful in calling forth this suspension, and to be clear that we read this as a kind of bridging, or bridged tension. Seeing the objects in the Sundry as occupying a state of suspension is something different entirely. One way to think about the objects in the Sundry is to imagine them in an extended moment of arrival, to recognize that the arrival of museum objects is an endless, recurring process. They are not just objects of attention for visitors, but active players on a stage of Sverrir's making (in his recognitions, in his collecting practices, in the museum site itself... each of the extended moments that bring about this collection... the process of selecting things from the house sites, the ordering of those things, the moving between spaces... all contribute to an ongoing sense of arrival). There is a tension, then, in the objects in the museum, a sense of endless becoming, belied by their static arrangements. The orderliness of the objects is actually a complicated way to indicate their disorder, or at least their coming to singularity.

Small, peripheral, idiosyncratic museums have been increasingly recognized as offering ways to re-imagine museum practice (see Candlin 2016, for example), in part through their active deconstruction of the master museum tropes of authority and explication exercised over objects fantastic and rare. Indeed, the Museum of Sundry Objects participates in this unsettling, both through the variety and categories of its collected objects, and through the density and immersive qualities of its exhibitionary practices. There are other museum spaces that seem to breach categories, that challenge the visitor's ability to comfortably navigate between sites for contemplation and distraction, and exercise in the potentially tongue-incheek (not as frivolity, but as an engagement with museum practice itself, a way to pull the visitor into a slowly unsettling narrative, as in the Phallogical Museum, for example, in which visitors are encouraged to think about the absent presence of a Hidden Man's penis in a gallery that includes more tangible leviathan and human members). The Museum of Jurassic Technology offers another venue where the slipperiness of 'truth-telling' in the exhibitions is slowly revealed as the visitor works their way into the museum's interior.

The Museum of Sundry Objects allows us to think carefully about a number of key elements of museum practice, including the logic of collection and the practice of object array. It also encourages us to think carefully about the role of the museum's 'heroic object' - one thing indicates many and serves as their sign - and the serial objects presented at the Sundry - one pencil cannot stand for many as all have different stories to tell. Being displayed in a group imparts even more individuality (agency) for each object, in part through making the human wear and handling of each of them more accessible and more of the life path of each object. Where the 'heroic object' wants one to move from the individual to the imagined array, the array opens a possibility for recognizing the singularity of objects. The signs of wear the pencils in their varying shortness, the shape of keys, the scratching of the strike bars on the matchboxes, the smoothed places of handles and tools - indicate the struggle between agency and individuality for the object, and category and typology for the collection. As Turkle suggests, 'Objects have life roles that are multiple and fluid' (Turkle 2011: 6).

But Sverrir's reach is not confined to the gallery and museum. As a skilled carpenter, his imprint is on many of the area's buildings, most often at the level of the unseen. His carpentry and restoration work is mostly out of the public eye, but his collection works to place things in the public eye. And the objects that get thus placed are often things that have fallen out of use and circulation (or out of visibility) - abandoned tools, cracker tins, utensils, cameras and, well, sundry objects. The museum works to make the mundane unseen, (the collected objects) visible, to operate as a cabinet of the mundane, articulated to serve as the curious, where 'the object's context of origin [is] replaced with the context of the collection' (McTavish 2006: 242). The museum also serves to deliver objects from the liminality of abandonment, ruin, and disuse to the liminality of the collection, the exhibition, and the museum display. As Sandra Dudley provocatively asserts: 
But from the object's point of view, the liminal phase not only concerns the moment in which artefacts become museum objects, but is also defined and, significantly, perpetuated by their subsequent and ongoing use as representational objects in other words, the very fact of being a museum object means the artefact, seen from its own perspective, is liminal, in between social worlds (Dudley 2017: 45).

In discussing the assembly of natural history specimens, Matthew Battles states: 'I want to understand how things come to take their place - especially in museums and collections - as embodiments of knowledge, artefacts out of time and nature, provoking curiosity and wonder. How they become objectified.' ${ }^{.} \mathrm{He}$ is particularly curious about the role of the holotype, and he questions how one exemplar can stand 'as avatar for the flashing, teeming, endlessly various individuals of the species'. Clearly, we can apply this question to the practice of the Sundry, to recognize its collections as arrested objects drawn from this 'teeming' of everyday life, the marks of use and nostalgia, forgetfulness and remembrance (the twin engines of any museum). What the Sundry brings to life are those objects beyond the holotypes, those that have swum in the teeming daily practices of the mundane.

Collection is a transformative process - it not only removes things from the flow of time and space, but it reconfigures them in a pattern of sense-making at the museum level. The 'transform[ation] of... matter into storytelling objects', ${ }^{2}$ enables objects to serve as 'handholds' en route to use and meaning. The Sundry offers a broadness of understanding, an ordering in place and a recognition of a skein of use, networks, memories, and projections that present an intersection where objects 'come alive', a place where they inhabit a particular crossing, a 'weaving' into a broader set of implications, suggestions, and lived realities. As in all things, and following Nabokov, will we ever really 'know' the lived life of the carpenter's pencil? Did it ever escape its designed function, slip off its moorings of measure and figuring of distances and spaces, to sketch out a quick graffiti? A love poem? A shopping list? We infer its life from its presence, its thingness, its occupation of a particular set of expectations. But one of the beauties of this collection and its exhibitionary spaces is a recognition of both category affirmation and contamination.

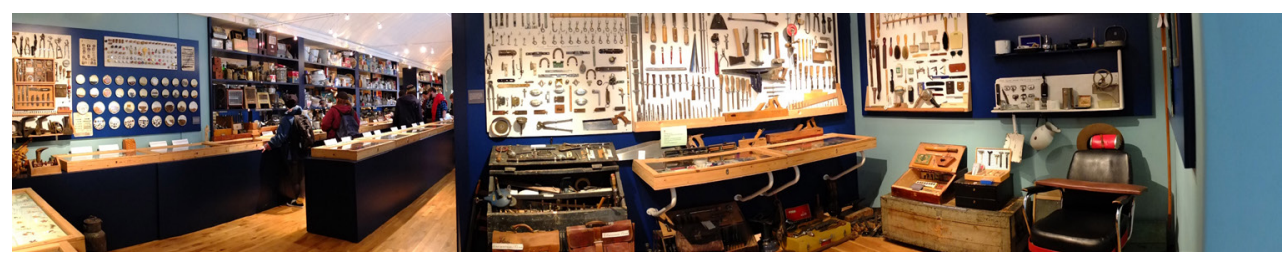

Figure 6.

The Sundry offers the visitor a deeply immersive experience, where the stillness of exhibition belies its endless 'becoming' and the process of the museum may be overlooked in its own stillness. We can peel away at the cabinets of curiosity component to reflect on how the arrangement of objects itself imparts meaning (or commands attention), and how the collection can be read as the output of a passionate collector. But limiting our understanding to those perspectives just scratches the surface of what is being offered here. This is not to suggest that the proper analytic frame will render the museum completely legible, or wrestle it down to a neat set of interpretive exercises. What the museum offers is a set of overlapping immersions and distractions, an embodied experience afloat in a dense atmosphere of overlapping signs and imagined object histories and biographies. The Sundry objects are arranged to engender and engage in conversations, in exchanges between the visitors and the objects themselves - they do not sit in arranged tableaux to be consumed, but function as sets of signs or characters on a line, able to be brought into different coherences through the exchange they demand. All collections are expressions of inclusion and exclusion - as all dances are combinations of steps taken, steps left behind, and steps not chosen. Dances carve coherence out of time and space. Place is taken, like pieces on a game board, like an invasion, like staked territory, through different patterns of occupation. 
As one of the Sundry's main exhibition components, we must pay careful attention to the familiarity of tools. The handedness of them, how they hold trace elements of touch, how they are shaped to respond, the stains of hand oils and accidents and experiences all embedded on the surfaces or dented down in deep, relaying histories. It is not hard to imagine the lives of these tools, nor is it hard to think that they now live in a state of arrest, a sort of limbo of practical usefulness, changed from one utility to a different set of utilities, held in place. The Sundry's objects advocate for an expanding understanding of time, as a way to consider the museum as a place of arrest (or even a resting place, a mausoleum). If we consider an object life in terms of glacial time, the museum life of things may be but a blip, a stage on a longer journey of becoming, 'a liminal phase during which [the object's] capacity to become re-enlivened may at any time be activated' (Basu 2017: 13). To scrub some of the metaphysical out of this - collections were not always collections and will not always remain collections; the rotation and direction of exhibitions indicates possible orbits of visibility and invisibility. Additionally, museums do not always survive, or survive in the state they are found. There are yet possible trajectories that would decouple the life of objects from their currently institutionalized states, that would position them in different spaces/places of awakening.

Institutional collections are not discrete networks of collected and ordered (finite) groupings, but entangled assemblages that cross back and forth between a number of different understandings and contexts. The Sundry's objects surface in different seas of knowledge-making, or sense-making. Their collection (the act of their being collected) gives a sense of coherence but, at the same time, the volume and variety counter-indicate a number of different trajectories for story-making and sense making. As Tsing suggests, perhaps this is a site for the upending of identities and the bursting of categories through a recognition of entanglement (Tsing 2017: 137). Strangely, the gathering of objects - which might encourage their being seen categorically - bursts this outcome, creating the space for the individual to be recognized among the herd. When we think about collections, one direction for contemplation is to consider how the objects come together - what logics do they reveal, what efforts cohered, what stories narrated? But, rather than looking for this kind of coherence, perhaps what may be worth considering more are the moments and fissures where the objects burst from whatever sort of arrangement they've been given or taken on as a set of identities or 'known' selves.

One of the key components to establishing evolutionary theory was the ability to think in huge expanses of time, the amount of time necessary for organic evolution. In some ways, the recognition of slow events calls for the same understanding of time, 'a liminality of unforeseeable duration' (Dudley 2017: 45), or something almost beyond our ken. One premise in contemporary museum-directed analysis is perfectly willing to consider the tangled lifeways and motivations that bring the object to collection, and to public view. But the temptation is also to imagine this as the end of the life of the object, that it has reached some sort of moment of arrest, it has been fully captured in the amber of the museum. I suggest that the museum may simply be one stage of many in the ongoing life of the object, a liminal phase or extended bridge over the abyss that offers a number of opportunities for the re-enlivening of the object, a different set of steps on the path of the inbetween. In part, the Museum of Sundry Objects supports this kind of pondering, since one response to many of the objects and tools is that they look perfectly useful, as if they could be plucked from the display and put to work, to re-enter the kind of use one imagines for tools - busy building, repairing, and tearing down. This is one of the more powerful outcomes of the Museum of Sundry Objects, and one that challenges the stasis of museum objects, the kind of frozen regard in which museum objects are often contemplated.

For a moment, let us return to Blom's image of order as a state of suspense over the abyss, a bridge across Benjamin's twin chaos of memory and passion, with a clear set of anchoring end points and a discrete length of passage. The Sundry allows us to recognize this suspension as both the 'long time' of slow events and distance; and as place, a territory of 'nearstasis'. The Museum offers two important things to consider: a re-imagination of object agency from the heroic to the array, and the reconsideration of the almost limitless territory of the museum object's liminal state. Here I circle back to Basu's concept of 'inbetweenness' to think about the ongoing state of museum objects, and to make the case for a significant 
extension of how we might imagine the liminal, to think of it less as a step or a stage and more as a territory entered, a continent or - as the title of this article suggests - an empire. Here it is important to consider what distinguishes an empire from a nation or other polity: the extent of it, the polyglot components of it, the centre for governance or order that extends out into different shapes of compromise and execution. In an empire, the boundaries of the known are often subject to revisions, new bodies of knowledge and constellations of objects are consumed or brought within the empire's limits, which both challenge and uphold the discreteness of familiar epistemic territory.

The Sundry offers a way to think about the extended liminal moment experienced by its objects (Dudley 2017) as something more than a bridge across the chaos and over the abyss, or some sequenced set of frames as part of an already fully imagined narrative trajectory. The Sundry presents a place where the play of objects carves out its own territory of the liminal and invites us to range within, at large, and, as Nabokov suggests, to exercise our 'act[s] of attention'.

Received: 17 November 2017 Finally accepted: 29 June 2020

\section{Acknowledgement}

With deep gratitude for support from the Fulbright-NSF Arctic Research Fellowship Program and Susquehanna University, and inspiration, research, and fellowship from Sigurjón Baldur Hafsteinsson and Sigríður Rósa Sigurðardóttir.

\section{Notes}

1 Matthew Battles, 'Specimens: Figurines, Fishers, Bugs and Bats - How Things in the World Become Sacred Objects in a Museum', Aeon, 2013. https://aeon.co/essays/amuseum-s-cabinet-of-curiosities-is-also-a-chamber-of-secrets, accessed 15 December 2018.

2 Battles, 'Specimens'.

\section{References}

Appadurai, A. (1986) 'Introduction: Commodities and the Politics of Value', in Arjun Appadurai (ed) The Social Life of Things, 3-63, Cambridge, UK: Cambridge University Press.

Basu, P. (ed) (2017) The Inbetweenness of Things: Materializing Mediation and Movement between Worlds, New York: Bloomsbury Academic Press.

Benjamin, W. (1968) 'Unpacking my Library', in Hannah Arendt (ed) Illuminations, 59-67, New York: Schocken Books.

Blom, P. (2003) To Have and to Hold, New York: The Overlook Press.

Candlin, F. (2016) Micromuseology, New York: Bloomsbury Academic.

Crane, S. (2000) 'Curious Cabinets', in Susan Crane (ed) Museums and Memory, 60-80, Stanford, CA: Stanford University Press.

Dudley, S.H. (2017) 'The Buzz of Displacement: Liminality among Burmese Court Objects in Oxford, London and Yangon', in Paul Basu (ed) The Inbetweenness of Things: Materializing Mediation and Movement between Worlds, 38-56, New York: Bloomsbury Academic Press. 
Kirshenblatt-Gimblett, B. (2006) 'World Heritage and Cultural Economics', in Ivan Karp, Corinne A. Kratz, Lynn Szwaja and Tomás Ybarra-Frausto (eds) Museum Frictions, 161-202, Durham, NC: Duke University Press.

McTavish, L. (2006) 'Visiting the Virtual Museum', in Janet Marstine (ed) New Museum Theory and Practice: An Introduction, 226-46, Malden, MA: Blackwell Publishing.

Nabokov, V. (1972) Transparent Things, New York: McGraw-Hill.

Neruda, P. (1974) 'Toward an Impure Poetry', in Ben Belitt (ed) Five Decades: Poems 1925-70, xxi-xxii, New York: Grove Press.

The Museum of Sundry Objects and Práinsdóttir, H. (2017) 'Sverrir Hermannsson's Saundry [sic] Collection', translated by Frances Jane Milne McQueen and Rafn Kjartansson [museum brochure].

Tsing, A. (2017) The Mushroom at the End of the World, Princeton, NJ: Princeton University Press.

Turkle, S. (2011) 'Introduction: The Things that Matter', in Sherry Turkle (ed) Evocative Objects, 1-10, Cambridge, MA: The MIT Press.

\section{Author}

John Bodinger de Uriarte

Chair, Associate Professor of Anthropology

Sociology \& Anthropology Department

Susquehanna University

United States

bodinger@susqu.edu 